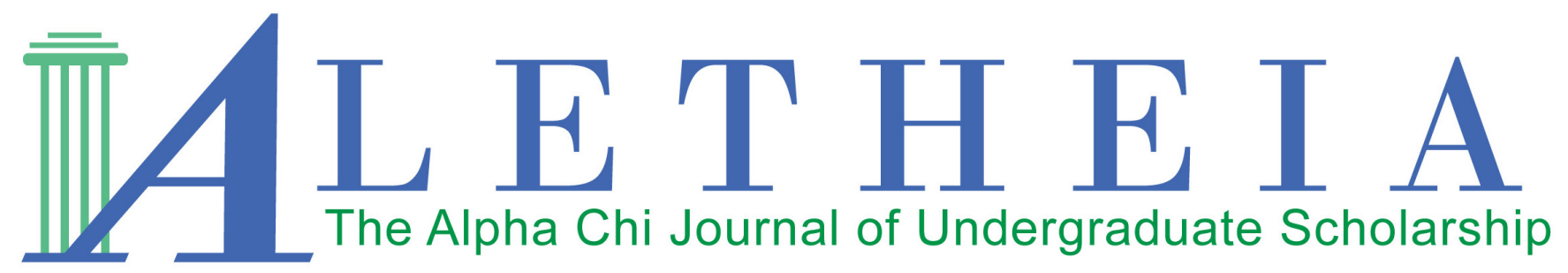

Volume 2 | Issue 2 | 2017

\title{
The Cry of the Cymry: Celtic Nationalism as a Response to Industrialization and Class in Wales in the 19th Century
}

\author{
McKinley Terry \\ Abilene Christian University \\ Texas Psi Chapter
}

Vol. 2(2), 2017

Article Title: The Cry of the Cymry: Celtic Nationalism as a Response to Industrialization

DOI: $10.21081 / \mathrm{AX} 0138$

ISSN: $2381-800 \mathrm{X}$

Key Words: Wales, nationalism, Celtic, 19th Century, industrialization, revolution This work is licensed under a Creative Commons Attribution 4.0 International License. Author contact information is available from the Editor at editor@alphachihonor.org.

\section{Aletheia-The Alpha Chi Journal of Undergraduate Scholarship}

- This publication is an online, peer-reviewed, interdisciplinary undergraduate journal, whose mission is to promote high quality research and scholarship among undergraduates by showcasing exemplary work.

- Submissions can be in any basic or applied field of study, including the physical and life sciences, the social sciences, the humanities, education, engineering, and the arts.

- Publication in Aletheia will recognize students who excel academically and foster mentor/mentee relationships between faculty and students.

- In keeping with the strong tradition of student involvement in all levels of Alpha Chi, the journal will also provide a forum for students to become actively involved in the writing, peer review, and publication process.

- More information and instructions for authors is available under the publications tab at www.AlphaChiHonor.org. Questions to the editor may be directed to editor@alphachihonor.org.

\footnotetext{
Alpha Chi is a national college honor society that admits students from all academic disciplines, with membership limited to the top 10 percent of an institution's juniors, seniors, and graduate students. Invitation to membership comes only through an institutional chapter. A college seeking a chapter must grant baccalaureate degrees and be regionally accredited. Some 300 chapters, located in almost every state, induct approximately 12,000 members annually. Alpha Chi members have been "making scholarship effective for good" since 1922.
} 


\title{
The Cry of the Cymry: Celtic Nationalism as a Response to Industrialization and Class in Wales in the 19th Century
}

\author{
McKinley Terry \\ Abilene Christian University \\ Texas Psi Chapter
}

\begin{abstract}
This paper traces the development of nationalism in Wales during the 19th century, particularly focusing on the resurgent interest in Celtic traditions, literature, and language. Beginning with an overview of the state of Wales in the late 18th century, this paper addresses the connections between Romanticism and Wales, as well as the prominent role of antiquarians such as William Owen Hughes and Edward Williams. From there, the paper analyzes the relations between the English landowners and their Welsh workers, demonstrating how these class tensions spurred on nationalism through cultural, political, and religious non-conformity. Industrialization played a significant role in this development, especially with the rise of factories and mines in what was previously a nation dominated by agriculture. In the face of such drastic alterations to their lives, a Welsh national identity began to coalesce around the Celtic heritage of the people. Festivals began to be held in Welsh, Nonconformist religious revivals provided a democratic opportunity for civic participation, and the percentage of the population fluent in Welsh increased throughout the 19th century. Utilizing original texts and the writings of contemporary Welsh scholars, this paper provides an examination of the rise of nationalism in Wales and its foundation in its Celtic past, as well as an explanation as to why Welsh nationalism was far more egalitarian and progressive than what was experienced elsewhere in Europe during the 19th century.
\end{abstract}

Key words: Wales, nationalism, Celtic, 19th Century, industrialization, revolution

To walk through Wales at the turn of the $19^{\text {th }}$ century was to walk through a land of far-reaching contrasts. It was a land that both embraced the newfound technologies of industrialization and clung to practices and traditions that pre-dated the arrival of the Romans on Britain's shores. The people sought both to reform British society and to emphasize the cultural differences between the Welsh and English peoples. Wales was, in short, a land precariously balanced between the approaching future and the receding past, its people unsure of their place in the world. The $19^{\text {th }}$ century, however, offered an opportunity for the Welsh people (Cymry) to discover some surety regarding their identity. To forge a new future, the Cymry first looked towards their past, drawing on their Celtic traditions and heritage. Just as nationalism spread throughout much of Europe, so too did it enflame the hearts of the Welsh. An often politically radical people already, the Welsh people embraced their culture and language once more, as well as a fierce democratic and egalitarian spirit for which they prided themselves. Amidst the turmoil of the $18^{\text {th }}$ and $19^{\text {th }}$ centuries, in which the French Revolution, Romanticism, and industrialization fundamentally altered the social and economic order of Europe, the Welsh people forged 
a national identity marked by political and religious radicalism that arose from their Celtic language, traditions, and literature.

At the turn of the $19^{\text {th }}$ century, the British government conducted a census of the population of England and Wales; the findings indicated that the population of Wales and Monmouthshire (sometimes included in measurements of the Welsh population and other statistics) made up one-fifteenth of the total population (586,634 people) (Rhys and Brynmor-Jones xix). Even with the inclusion of what is more accurately an English county, Wales makes up a tiny portion of the British population. This is, of course, reasonable given its geographic size. At its longest, Wales ranges 135 miles from its southern to northern coasts (comparable to the US state of New Jersey) (xv). Nevertheless, this diminutive nation and its people have played an integral role in the development of Britain throughout history. At the turn of the $19^{\text {th }}$ century, Wales was "an economically and socially backward part of Great Britain which was overwhelmingly rural, sparsely populated and without a centre" (Löffler 2). The people there were predominantly farmers and shepherds living in isolated villages spread throughout the mountain ranges and dense forests. Their isolation was only compounded by the social degradation of the past centuries.

Ever since England's conquest of Wales, the old Celtic identity of the British tribes had been in conflict with English culture and governance, and typically the English proved victorious. By the $18^{\text {th }}$ century, "the native legal system was abolished, the bardic system atrophied, the old language was outlawed from administration, and, although the official classes such as the gentry and professional tradesmen still spoke Welsh, their attitudes became anglicised" (Hobsawn and Rangers 44). Such disintegration of culture and tradition was only exacerbated by economic differences. The few Welsh gentry that did exist (most property was owned by English overlords) increasingly sought to be viewed as English, even avoiding teaching their children Welsh "lest it should spoil their English accent for the rest of their lives" (Rhys and Brynmor-Jones 513). London became the center of the gentrified Welsh, thus leaving the majority of the Welsh to the far-flung regions where they sought to scrape a living from fields and flocks. The English government would later comment on this isolation, arguing that the average Welshman "jealously shrinks from holding any communion with classes either superior to, or different from, himself" (Committee of Council on Education 4). The Welsh were viewed as backward and primitive, removed from the beacons of civilization and culture that were English towns and governance.

That the gentry and upper-classes in Wales became removed from the workers was only made worse by their disregard for the Welsh language itself. For several centuries, the Welsh aristocracy had sought to eliminate the use of the language as a way to appease the English and increase their status. John Rhys, the first professor of Celtic at Oxford University, wrote that "we find evidence of a desire on the part of many Welshmen to get rid of the language...this was the attitude, doubtless, of the bulk of the educated and well-to-do classes" (Rhys and Brynmor-Jones 513). Though this zeal for Anglicization had receded by the $19^{\text {th }}$ century, the upper classes of Wales were still removed from their people through their minimal grasp of their own language. Celtic revivalists "observed a gradual decline in the grasp that Welsh literati had of the traditional culture, its symbols, language, grammar" (Hobsawn and Rangers 47). At the turn of the $19^{\text {th }}$ century, the Welsh people found themselves fiercely divided along economic and linguistic lines at a time when such divisions were guaranteed to cause tension and change.

These tensions only became more evident and pervasive with the cultural changes and revolutions which took place at the turn of the $19^{\text {th }}$ century. Across the English Channel, the French people rose up against the monarchy, engaging in a bloody and chaotic revolution that quickly horrified English sensibilities. Even many liberals in Britain, initially supportive of what they saw as an egalitarian uprising promising a future of justice and freedom for the French people, turned against the violent excesses of the revolution. Against the backdrop of revolution, the Welsh people were viewed with suspicion (Constantine and Johnston 7). Though relations between the English and Welsh had been relatively peaceful for many years, the Welsh were still often viewed as eccentric and potentially dangerous. The English recognized that the majority of the Welsh people were sustained by agricultural ventures that, while they provided subsistence, rarely provided prosperity; 
and in the face of the French Revolution, the English understood the danger such impoverishment posed to the order and stability of British society. Even when the majority of political and religious leaders in Wales declared unreserved loyalty to the government and king, as was prevalent even among radical dissenters, such actions were viewed with a cautious distrust (Löffler 93). The political turmoil of the late $18^{\text {th }}$ and early $19^{\text {th }}$ centuries made the English fully aware of the dangers posed by the tensions between them and their Welsh neighbors.

Industrialization throughout Wales and England further increased anxiety on the part of the English and the Anglicised Welsh gentry. The French Revolution had demonstrated the danger posed by rampant inequality and injustice. Without reform, injustice would be met by unrest and violence, and the industrial capitalists of Britain began to fear they might face similar fates. Though Wales possessed a history of occasional uprisings against English rule, the past several centuries had been relatively peaceful. As tensions grew, however, so too did the threat of violence. Industrialization brought about an unprecedented increase in population, so much so that by the end of the $19^{\text {th }}$ century the population of Wales had more than tripled (Rhys and Brynmor-Jones xviii). Most of this growth took place due to the formation of industrialized towns for mining, especially in the south with cities like Merthyr Tydfil (Newell and Watts 315). Agricultural innovations meant that the diet of the Welsh people improved at the turn of the $19^{\text {th }}$ century, resulting in larger families in which fewer children died young (Rhys and Brynmor-Jones $\mathrm{xxi}$ ). This meant that an increasing amount of working-class Welsh people filled the nation, and the industrialists began to recognize the threat this posed to the social order. Labor became fiercely divided between the Welsh miners and their predominantly English managers who continued to grow more isolated from their laborers.

That the English often entirely disregarded Welsh culture and history only exacerbated these tensions, as evidenced by the publication of the Reports of the Commissioners of Inquiry into the State of Education in Wales in 1848. Ordered by Parliament as an effort to demonstrate that the Welsh remained ignorant and backwards, the reports arose from concerns about the pre-eminence of the Nonconformist religion and radical political movements among the Cymry. The reports were unforgiving and unreserved. The commissioners concluded that for a Welshman, "equally in his new as in his old home, his language keeps him under the hatches, being one in which he can neither acquire nor communicate the necessary information. It is a language of old-fashioned agriculture, of theology, and of simple rustic life, while all the world about him is English" (Committee on the Council of Education 4). Those commissioned by Parliament determined that the best policy to pursue would be the discouragement of Welsh. Only then, they concluded, could the barbaric and primitive Welshman be permitted to evolve like his orderly and mature English brethren. To do otherwise would be to risk violence and rebellion.

The reaction to these reports was immediate and fierce: "The Welsh responded by seeking to 'resurrect the old country' in terms that countered the slanderous tongues of English commissioners and journalists, while also living up to a British ideal of sobriety, moderation and docility" (D. Williams 283). Political conservatives and radicals alike condemned the reports, defending the education tradition within their country. For example, Lord Aberdare, "though he had no special sympathy with the Celtic Revival and the movement for Welsh Nationalism, yet Wales was his home, and he was always at the service of the people, and took great interest in the movement for extending education among the working classes" (J. Morgan, "Welsh Political and Educational Leaders" 21). Of course, Wales faced deficiencies in education, they admitted, but these deficiencies were shared among rural English, Scottish, and Irish communities and were in no way exclusive to Wales. Beyond this, the suggestion that the Welsh abandon their language as a means of cultural progression disgusted the entire nation. The Cymry viewed the reports not as an encouragement for reform and improvement as suggested by Parliament, but instead as merely another step in the suppression of their language, culture, and national identity. This reaction should not be surprising. After all, "a language, in a very real sense, is the pedigree of a people; for a Welshman, it unlocks centuries of Welsh experience, of a unique way of symbolizing the world and expressing human emotions and social relations" (Khleif 60). To attack the Welsh language was to attack the Welsh them- 
selves, and this was untenable for a people who had already experienced centuries of oppression at the hands of their English neighbors. For the Cymry, this was a fight for their very souls. It was also a fight they did not intend to lose.

The English, of course, saw the issue differently. The French Revolution and other conflicts in Europe had taught them to fear the power of the working class, especially when divisions of labor were so fiercely established, as was the case in industrialized Wales. The English feared violence, and these concerns were not without some justification. In the autumn of 1800, several radical Welshmen had led a riot that prevented the transportation of grain to the English military forces in Merthyr Tydfil; three of these men, ironworkers from the local factory, were summarily put to death to quell any further uprisings (Löffler 25). In the Reports the commissioners warned that the average Welshman "is left to live in an under-world of his own...is never heard of, excepting when the strange and abnormal features of a Revival, or a Rebecca or Chartist outbreak, call attention to a phase of society which could produce anything so contrary to all that we elsewhere experience" (Committee on the Council of Education 4). The commissioners reference the Rebecca Riots, several hundred violent uprisings against property and gentry throughout southwest Wales in the 1830s and 1840s (Rees 46). The Reports also mention the Chartist uprising that took place in Newport in 1839 when 22 Chartist protestors (men and women who demanded a written constitution to secure the rights of British citizens) were killed by the military while attempting to free their comrades from imprisonment (The Chartist riots at Newport: November, 1839 39). It would, therefore, be unjustified to argue that the concerns of the English were unfounded and based only on prejudice against the Welsh.

Nevertheless, most participants in chartist and labor movements in Wales during the first half of the $19^{\text {th }}$ century were peaceful and orderly. The vast majority sought a way to define their national identity through legal and respectable means. This is not to say that chartists were unique to Wales; in fact, the heart of the movement existed in England. Nevertheless, the Welsh people saw such a democratic and egalitarian movement as synonymous with their own national spirit. If there was to be a movement for a written constitution, they argued, the Welsh would lead that movement as they often had for other egalitarian efforts. Some of these leaders, such as John Frost and Ernest Jones, embraced the Marxist thought of the $19^{\text {th }}$ century and viewed democratic and chartist movements as a way to promote the cause of the proletariat (K. Morgan 30). For many people of Wales, these radical political movements offered them opportunities to differentiate themselves from the English and establish a national identity that the Cymry had for so long been denied. Though violence often marked these movements, violence did not define them.

In response to the Reports and the other efforts on the part of the English upper class to quell Welsh culture, the Cymry embraced radical political and religious movements. This should not have surprised the English. The Welsh possessed a longstanding tradition of democratic and egalitarian efforts throughout their past, efforts that they often used as examples of their national character. For example, the Welsh had fought for the abolition of the slave trade long before the rise of William Wilberforce in Parliament, and afterwards they continued to fight for the abolition of slavery throughout the world (D. Williams 53). Elsewhere, many of the Welsh led efforts that resulted in labor reforms and the eventual disestablishment of the workhouses that had for so long been unwittingly used to perpetuate a vicious cycle of urban poverty (Evans and Jones 104). Though not all Welsh people were radical, or even liberal, radical political movements found fertile ground in the quarries and mines of Wales. The Liberal Party, and eventually Labour in the early $20^{\text {th }}$ century, received vocal and widespread support, and the early efforts of chartists and other democratic groups led to an acceptance of socialism that was otherwise unprecedented in Britain (Wright 4).

These radical political movements were embraced by the miners and laborers in the slate-quarries and iron mines throughout Wales. Industrialization had more fiercely divided labor throughout Britain, but it did offer opportunities for economic empowerment for people who otherwise would have been completely at the mercy of the English. In contrast to the gentry who too often abandoned the Welsh language and culture, quarries and mines became fertile ground for the sustenance of the Celtic 
spirit of the Cymry, so much so that "the Welsh slate quarries naturalized the relationship between the activities of slate-quarrying and speaking Welsh, indirectly making themselves the ideal replacements in the nationalist imaginary for a vanishing Welsh-speaking 'peasantry' as Volkisch exponents of the Welsh nation" (Manning 481-482). If language is integral to the preservation of a culture, then the working class of Wales embraced their role as the bulwark against complete Anglicization (Ellwood 782). For the Welsh laborers, to speak the language connected them with their identity as a people distinct from their English neighbors. Even conservative individuals such as the Reverend J. Vyrnwy Morgan acknowledged that the Celtic nature of the Welsh language preserved traits such as "mysticism, idealism, spiritual finesse, power of expression or imagination, and of sentiment or religious fervour" (J. Morgan, "Philosophy of Welsh History" xiii). Laborers spoke Welsh whether or not those who owned the mines and quarries could understand them, and they developed their own processes by which their labor was made more productive and valuable.

The Cymry even went so far as to argue that their identity as Welsh made such productivity possible, maintaining that "Welsh is the language of the land and the quarries, and Welsh is what the rocks, and the sheep who browse our slopes, have learned. The English thought that there was a way to work our quarries...in English, and do twice as much of everything" (Manning 492). Outside of the quarries, the Welsh language was preserved in the public houses that arose during industrialization as centers of leisure and relaxation. Here, the laborers both preserved their culture and gathered in what would become the forerunners to labor organizations and politically-charged alliances (Pritchard 332). Whether true or not, the Welsh prided themselves that they were more productive than the English, asserting their cultural pride with what they considered the language of the rocks and the sheep and reforming their status as a people with each blow of the pickaxe and hammer.

Beyond specific policies, the Welsh people also began to promote widespread and egalitarian education throughout their entire nation. The $19^{\text {th }}$ century saw the founding of Cardiff University, University College of North Wales (now Bangor University),
Trinity University College (now part of University of Wales, Trinity Saint David), and University College Wales (now Aberystwyth University), among others (J. Morgan, "Welsh Political and Educational Leaders" 12). By 1877, the future Sir John Rhys was made the first professor of Celtic at the University of Oxford, a major milestone in the respect paid to the studies of Celtic history and culture. Due to the efforts of Nonconformist religious leaders, education became more widespread than ever before in Welsh history as a way of protesting their denigration at the hands of the English (Cragoe 120). The people of Wales made every effort to disprove the allegations levelled against them in the 1847 Reports and were largely successful in their endeavors.

This promulgation of egalitarian education arose primarily from the fiercely liberal nationalism that now permeated Wales. Sir Hugh Owen advocated for widespread educational opportunity, advancing his efforts by appealing to the Cymry: "you feel the necessity of giving education to your children, and you love liberty of conscience...in order to secure liberty of conscience, you must have schools which shall not be identified with any particular religious denomination" (J. Morgan, "Welsh Political and Educational Leaders" 199). Welsh leaders believed that education was a means of empowerment and liberation, and they sought to empower as many of their countrymen and women as possible. To do so, they looked to the popularity and pervasiveness of Nonconformist religious groups throughout Wales.

Perhaps the strongest force that pushed the Welsh people to a politically radical version of nationalism was the prevalence of the Nonconformist religion among the people. Celtic Christianity in Britain had long operated differently from the Roman Catholic Church, and religious traditions in Wales during the $19^{\text {th }}$ century were likewise distinct from the established Anglican church. Due to the popularity of Methodist revivals, "the great majority (after 1811) were Nonconformists, and by 1843 or so they had become 'Dissenting,' in a more positive sense perhaps than they are to-day" (Jenkins 163). Of course, this majority was made up of the working class. The gentry, however, had for so long sought to be accepted by the English that their Anglicization reached even religion. While farmers and miners made up the ranks of the Nonconformists and Dissenters, the 
Anglican churches provided a measure of increased respectability to the gentry. The working class gathered together in a religious gathering known as the Seiet, a society where religious and literary discussions could be held exclusively in Welsh. This Seiet, "composing every church member, is, in a word, a miniature democracy, with the power residing in the elders and the other communicants, and not in the minister, whose presence, though usual, is not essential to the workings of the system" (Rhys and Brynmor-Jones). The Celtic spirit of egalitarianism and community thrived within the religious practices of the working-class Cymry. Just as the political radicalism that marked Wales throughout the second half of the $19^{\text {th }}$ century arose from the working-class peasantry, so too did the religious nonconformity: "an ethnic conception of Welshness developed in the nineteenth century, rooted in Nonconformity...it might be viewed as a form of early Welsh nationalism" (D. Williams 279). The cultural identity of the Cymry arose from the working-class laborers whose efforts helped to form an unprecedented nationalism for Wales.

The rise of Welsh identity and radicalism can also be attributed to the pre-eminence of Romanticism as a philosophy in the late $18^{\text {th }}$ and early $19^{\text {th }}$ centuries that persisted even longer in Wales than in England. Though Wales had for centuries been ignored politically, "Wales was imagined: as a picturesque landscape of disparate mountains, rivers and valleys peopled by natives endowed with an exotic language and literary culture" (Löffler 19). Industrialization would mar some of the natural beauty of Wales, but it could never conquer it (Zaring 412). After all, it was in Wales that Wordsworth would pen one of his most famous poems, "Lines Composed a Few Miles above Tintern Abbey," writing, "these waters, rolling from their mountain streams / With a sweet inland murmur. - Once again / Do I behold these steep and lofty cliffs / Which on a wild secluded scene impress / Thoughts on a more deep seclusion" (Halmi 65-66). Wales was the wilderness of imagination, a fertile land of myth and legend even in the $19^{\text {th }}$ century. As Romanticism spread, so too did interest in the Celtic ways of Welsh antiquity, and with such interest did the pride of the Cymry increase. Welsh poets were aware of their subsequent responsibilities, understanding that "to ponder a nation's poetical past is to sharpen one's awareness of its political past" (Jones xxiv). If Wales was to capture the popular imagination, its full identity as a nation must be articulated. Nothing less would suffice for the pride of the Welsh people.

Romanticism throughout Britain also inspired culturally-minded Welsh gentry to fight for the preservation of Welsh culture. From the second half of the $18^{\text {th }}$ century onward, a group of Welsh antiquarians in London began to promote the preservation of ancient Welsh writings and practices, as well as the expansion of cultural events. To these individuals, the degradation of the Celtic past of Wales was abhorrent. The poet Felicia Heman, whose works regarding the plight of the Cymry were condensed in A Selection of Welsh Melodies in 1822, wrote in "The Ruins of Denbigh Castle" that "yet not the dirge, that soft and slow, / Murmurs the plaintive tale of woe; / Not to lament these tw'rs decay'd, / Their glory low, forgotten laid" (Edwards 85). The grief and sorrow of those Cymry cherishing their Celtic past as it faced the constant assault of Anglicization resounded in their poetry, as rich and vibrant as ever yet now full of agony. Ieuan Fardd wrote in the late $18^{\text {th }}$ century of a similar grief, viewing the ruins of the great chieftain Ifor Hael's hall and declaring that "There's no more genius there, / No bards or boards of joy; / No gold within its walls, / No mail, no generous giver" (Jones 137). To the poets of Wales, the ruins of the old fortresses and halls of their forebears were a constant reminder of a past that seemed to be slipping even further away. Once the Cymry were proud lords and rulers of their own kingdoms; now they were subjects to English overlords whose actions suppressed them both economically and culturally.

Along with the pre-eminence of Romanticism and an effort to preserve and promote Welsh literature came the revival of the Eisteddfod, a literary gathering where prose, poetry, and other tracts were presented publicly in contest and competition. Prominent London-based Welsh individuals such as Edward Williams (who adopted the bardic name Iolo Morganwg) helped lead this resurgence that provided a Celtic foundation for Welsh nationalism (Constantine 233). He and his compatriots sought to compile ancient Celtic texts from Britain and make them available to the public, most famously condensed in the Myvyrian Archaiology, edited by Morganwg, 
Owen Jones, and William Owen Pughe (T. Williams). Though historians would later determine that some of the writings included in the collections were actually forgeries written by Morganwg himself, their collections still provided the people of Britain with widespread access to the early legends and poetry of the Celtic people of Wales. Beyond the Myvyrian Archaiology and the Eisteddfod, Lady Charlotte Guest published the first English translation of the stories that make up what is known as the Red Book of Hergest. Her collection, titled The Mabinogion, maintained that the myths and legends of Wales made up the foundation of later European romance (Guest xii). This promulgation of Celtic literature and traditions enabled the Welsh people to once more connect with their culture in a way that had been denied them for centuries, and in doing so they forged for themselves a fierce and radical nationalism.

Matthew Arnold would later explain what he believed to be the cause of the Welsh people's propensity for radical politics and religion, and he connected such tendencies directly to their Celtic nature. According to Arnold, "Sentiment is, however, the word which marks where the Celtic races really touch and are one...an organisation quick to feel impressions, and feeling them very strongly; a lively personality therefore, keenly sensitive to joy and to sorrow; this is the main point" (100). Romanticism appealed to the fierce connection the Cymry possessed with their land. Political radicalism appealed to their fullness of spirit and enthusiasm for equality. Nonconformist religion appealed to their emotionalism and creativity of spirit. John Rhys, though seeking to avoid caricaturing the Welsh people, would acknowledge that "we should perhaps be safe in assuming that the Welsh...participate in this greater impulsiveness and liveliness of imagination" (Rhys and Brynmor-Jones 591). Radicalism appealed to their Celtic sensibilities, and the Welsh people based their nationalism on this proud, boundless spirit.

Such fierceness of spirit arose within the distant past of Welsh history and legend, but it had not faded by the onset of the $19^{\text {th }}$ century. Iolo Morganwg would write during the French Revolution that soon "fair sunshine will arrive in our skies, / beautiful sky, it will provide a warm time; / the songbird from the citadel of heaven / will proclaim the pure cry of truth and its might; / truth and its battle against kings / will be on his lips with angry cry" (Charnell-White 195). Detailing the grief that many of the Welsh experienced, John Ceirog Hughes (one of the earliest members of the National Eisteddfod) embraced the romanticism and sentimentality of his people during the $19^{\text {th }}$ century when he wrote "Passing with the passing years / Ancient customs change and flow; / Fraught with doom of joy or tears, / Generations come and go. / Out of tears' and tempests' reach / Alun Mabon sleeps secure;- / Still lives on the ancient speech, / Still the ancient songs endure" (Jones 142). Like their ancestors, the Welsh writers of the $19^{\text {th }}$ century revealed the sentimentality and passion of the Celtic spirit that defined the Cymry, a spirit that reflected a people who Arnold maintained "is the more down because it is so his nature to be upto be sociable, hospitable, eloquent, admired, figuring away brilliantly. He loves bright colours, he easily becomes audacious, overcrowing, full of fanfaronade" (Arnold 101). Against the backdrop of industrialization and conflict in Europe, the Welsh people established their identity as a separate ethnic group in Britain by embracing this Celtic spirit.

The legends of Wales reflect the mystical connection between people, land, and past on which Romanticism focused. Arnold maintained that for their literature, "all is illusion and phantasy, double-meaning, and far-reaching mythological import, in the world which all these personages inhabit" (Arnold 60). Lady Charlotte Guest detailed how the Welsh often connected their legends to the land itself; to them, poetry and myth was invariably dependent on the land, and the land was invariably dependent on poetry and myth (Guest xi). Like any civilization, the pride of the Welsh in their land and heritage arose from their legends and literature, and their poetry was a cultural cornerstone upon which all else was constructed.

With the onset of Romanticism, the Industrial Revolution, and changing political orders throughout Europe, the Welsh people sought to find a means of establishing their unique national identity. Rather than succumb to the influence of Anglicization, the Cymry embraced and celebrated their Celtic identity by promoting their legends and poetry, demanding respect for the labor and rights, and fighting for egalitarian and democratic causes throughout Britain. The efforts of the Welsh during the $19^{\text {th }}$ century were 
largely successful. As a culture, they became more respected throughout Great Britain. Oftentimes this success was aided by Englishmen like Arnold who "established a connection between Celtic genius and poetry which helped to authorize the cultural privileging of poetry in the narrative of Welsh literary history" (Fulton 219). People throughout Britain came to better understand the Welsh, realizing that "with their sensuous nature, their manifold striving, their adverse destiny, their immense calamities," the Cymry of Wales were a proud and powerful people (Arnold 152). Welsh people became leading members of radical political organizations, bringing about significant reforms in society through abolition and labor relations. They advocated the dignity and value of working-class laborers, and they led Nonconformist religious revivals that helped to better define their status as a people. They founded universities and schools, and such was the credibility of their efforts that in 1877 Oxford University appointed John Rhys to be its first Professor of Celtic. In creating for themselves a new national identity, one founded in their Celtic heritage, the Cymry resurrected their ancient hopes of national dignity as spoken by the prophetic bard Taliesin: "Britons then shall have / Their land and their crown, / And the stranger warm / Shall disappear. / All the angel's words, / As to peace and war, / Will be fulfilled / To Britain's race" (Guest 209). A politically and religiously radical people, the Welsh of the $19^{\text {th }}$ century established for themselves a fierce and proud national identity, an identity arising from the Celtic soul of the Cymry that would not now fade away from the Island of the Mighty.

\section{Works Cited}

Arnold, Matthew. On the Study of Celtic Literature, Smith, Elder, and Co., 1867.

Charnell-White, Kathryn A. Welsh Poetry of the French Revolution: 1789-1805, University of Wales Press, 2012.

Committee of Council on Education. Reports of the Commissioners of Inquiry into the State of Education in Wales. William Closes \& Sons, 1848.

Constantine, Mary-Ann. "Songs and Stones: Iolo Morganwg (1747-1826), Mason and Bard." The Eighteenth Century, vol. 47, no. 2/3, 2006, pp. 233-251.
Constantine, Mary-Ann, and Defied Johnston, editors. 'Footsteps of Liberty and Revolt': Essays on Wales and the French Revolution. Cardiff University Press, 2013.

Cragoe, Matthew. "Welsh Electioneering and the Purpose of Parliament: 'From Radicalism to Nationalism' Reconsidered." Parliamentary History, vol. 17, no. 1, 1998, pp. 113-131.

Edwards, Elizabeth. "Lonely and Voiceless Your Halls Must Remain': Romantic-Era National Song and Felicia Human's Welsh Melodies (1822)." Journal for Eighteenth-Century Studies, vol. 38, no. 1, 2015, pp. 83-97.

Ellwood, Charles. "Theories of Cultural Evolution." American Journal of Sociology, vol. 23, no. 6, 1918, pp. 779800.

Evans, Megan and Peter Jones. "A Stubborn, Intractable Body': Resistance to the Workhouse in Wales, 18341877." Family \& Community History, vol. 17, no. 2, 2014, pp. 101-121.

Fulton, Helen. "Matthew Arnold and the Canon of Medieval Welsh Literature." The Review of English Studies, vol. 63, no. 259, 2011, pp. 204-224.

Guest, Lady Charlotte E. The Mabinogion, Dover Publications, 1997.

Halmi, Nicholas, editor. Wordsworth's Poetry and Prose, W.W. Norton and Company, 2014.

Hobsawn, Eric and Terence Ranger, editors. The Invention of Tradition, Cambridge University Press, 1983.

Jenkins, R. T. "The Development of Nationalism in Wales." The Sociological Review, vol. 27, no. 2, 1935, pp. 163182.

Jones, Gwyn, editor. The Oxford Book of Welsh Verse in English, Oxford University Press, 1977.

Khleif, Bud B. "Language as an Ethnic Boundary in Welsh-English Relations." International Journal of the Sociology of Language, vol. 1979, no. 20, 1979, pp. 5974.

Löffler, Marion. Welsh Responses to the French Revolution: Press and Public Discourse 1789-1802. University of Wales Press, 2012.

Manning, H. Paul. "English Money and Welsh Rocks: Divisions of Language and Divisions of Labor in Nineteenth-Century Welsh Slate Quarries." Comparative Studies in Society and History, vol. 44, no. 3, 2002, pp. 481-510.

Morgan, J. Vyrnwy. The Philosophy of Welsh History, John Lane, the Godley Head, 1914.

Morgan, J. Vyrnwy. Welsh Political and Educational Leaders in the Victorian Era, James Nesbit \& Co., Limited, 1908.

Morgan, Kenneth O. Revolution to Devolution: Reflections on Welsh Democracy, University of Wales Press, 2014.

Newell, Edmund and Simon Watts. "The Environmental Impact of Industrialization in South Wales in the Nine- 
teenth Century: 'Copper Smoke' and the Lamella Copper Company." Environment and History, vol. 2, no. 3, 1996, pp. 309-336.

Pritchard, Ian. "'Beer and Britannia': public-house culture and the construction of nineteenth-century British-Welsh industrial identity." Nations and Nationalism, vol. 18, no. 2, 2012, pp. 326-345.

Rees, Lowry A. "Paternalism and rural protest: the Rebecca riots and the landed interest of south-west Wales." The Agricultural History Review, vol. 59, no. 1, 2011, pp. 36-60.

Rhys, John and David Brynmor-Jones. The Welsh People: Chapters on Their Origin, History, Laws, Language, Literature, and Characteristics. The Macmillan Company, 1900.

The Chartist Riots at Newport: November, 1839, W.N. Johns, 1889.

Williams, Daniel G. "Uncle Tom and Edythe Robert: Anti-Slavery and Ethnic Reconstruction in Victorian Wales." Slavery and Abolition, vol. 33, no. 2, 2012, pp. 275-286.

Williams, Taliesin. Iolo Manuscripts: A Selection of Ancient Welsh Manuscripts. William Rees, 1848.

Wright, Martin. "Wales and Socialism: Political Culture and National Identity." PhD Thesis, Cardiff University, 2011.

Zaring, Jane. "The Romantic Face of Wales." Annals of the Association of American Geographers, vol. 67, no. 3, 1977, pp. 397-418. 